\title{
PENYELESAIAN SENGKETA EKONOMI SYARIAH DI PENGADILAN AGAMA BEKASI
}

\author{
Ummi Azma*
}

\begin{abstract}
In interacting with each other in community life often leads to conflict. This conflict can sometimes be resolved peacefully, but occasionally the conflict creates ongoing tension that causes losses on both sides. In order to defend the rights of each party it does not exceed the limits of the prescribed norm, the act of its own accord should be avoided. If the parties feel that their rights are disrupted and incur losses, then the person who feels his right is disadvantaged can file a lawsuit to the Religious Courts in accordance with the applicable procedures. This article is a summary of research results on the settlement of the Sharia economic dispute in the Religious Court of Bekasi.
\end{abstract}

Kata kunci: hukum islam, ekonomi syariah, pengadilan agama.

Selama ini, pengertian ekonomi disamakan artinya dengan kata "iqtishad" dalam bahasa Arab artinya hemat dan penuh perhitungan. Menurut Bagir al-Hasani sebagaimana yang dikutip oleh Agustianto, bahwa istilah ekonomi dan iqtishad merupakan dua konsep yang berbeda, meskipun banyak ulama yang mengartikan sama antara keduanya. Kata iqtishad merupakan derivasi dari kata qash yang mempunyai arti equilibrium (keseimbangan atau pertengahan) atau "the state of being even, equal balanced, or evenly in between" sehingga kata iqtishad berarti "that which evenly in between two extremes". Lebih harmonisnya lagi apabila diambil hadis Nabi SAW: "Alaikum Hadyan Qashidan" (follow the middle of the road), maksudnya diwajibkan atas kamu menempuh jalan tengah. (Agustianto, 2002: 4).

Dari berbagai pendapat pakar ekonomi tentang definisi ekonomi syariah, maka dapat disimpulkan bahwa ilmu ekonomi syariah adalah ilmu yang mempelajari aktivitas atau perilaku manusia secara aktual dan empirikal, baik dalam produksi, distribusi, maupun konsumsi berdasarkan syariat Islam yang bersumber Al-Qur'an dan As-Sunnah serta ijma' para ulama dengan tujuan untuk mencapai kebahagiaan dunia dan akhirat. Ekonomi syariah bukan sekedar etika dan nilai yang bersifat normatif, tetapi juga bersifat positif sebab ia mengkaji aktivitas aktual manusia, problemproblem ekonomi masyarakat dalam persfektif Islam. Dalam ekonomi Islam baik konsumen maupun produsen bukanlah raja. Perilaku keduanya harus dituntun oleh kesejahteraan umum, individual, dan sosial sebagaimana yang telah ditetapkan oleh Islam.

Dengan demikian, maka dapat diketahui bahwa Islam memiliki sistem ekonomi yang secara fundamental berbeda dari sistem ekonomi yang lain. Sistem ekonomi Islam memiliki akar syariat yang membentuk pandangan dunia, strategi, dan sasaran yang berbeda dengan sistem sekuler yang menguasai dunia saat ini. Konsep ekonomi Islam sasarannya tidak hanya didasarkan kepada materiil saja, tetapi mencakup juga hal-hal yang immaterial, seperti kebahagiaan manusia (al-falah), kehidupan yang baik

*Pengadilan Agama Kelas IA Bekasi Jawa Barat, alamat koreponden penulis e-mail:pa.bekasi_ptabdg@yahoo.co.id. 
(hayatan thayyibah), aspek persaudaraan (ukhuwwah), keadilan sosio ekonomi dan kebutuhan-kebutuhan spiritual umat manusia lainnya.

Aktivitas ekonomi dalam pandangan Islam mempunyai tujuan antara lain:

1. Memenuhi kebutuhan hidup seseorang secara sederhana.

2. Memenuhi kebutuhan keluarga baik yang dharuri, dhanni, maupun yang taksini.

3. Memenuhi kebutuhan jangka panjang.

4. Menyediakan kebutuhan keluarga yang ditinggalkan.

5. Memberi bantuan sosial dan sumbangan bagi yang memerlukan sesuai dengan ketentuan yang ditetapkan Allah SWT.

6. Menerapkan ilmu ekonomi dalam praktik sehari-hari bagi individu, keluarga, kelompok masyarakat dan pengusaha dalam rangka mengorganisasi faktor produksi, distribusi, dan pemanfaatan barang dan jasa yang dihasilkan berdasarkan syariat Islam.

Para ahli ekonomi Islam telah merumuskan prinsip-prinsip ekonomi Islam, meskipun ada perbedaan dalam tata urutan tetapi substansinya sama satu dengan yang lainnya. Menurut Muhammad, bangunan ekonomi Islam diletakkan pada lima fondasi yaitu ketuhanan (ilahiah), keadilan (al-'AdI), kenabian (al-Nubuwah), pemerintahan (al-Khalifah), dan hasil (al-Ma'ad) atau keuntungan. Kelima fondasi ini hendaknya menjadi aspirasi dalam menyusun proposisi-proposisi atau teori-teori ekonomi. (Muhammad, 2004: 95).

1. Nilai Ketuhanan (Ilahiah)

Nilai ini beranjak dari filosofi dasar yang bersumber dari Allah dengan tujuan semata-mata untuk mencari ridha Allah semata (li-mardhatillah). Oleh karena itu, segala kegiatan ekonomi yang meliputi permodalan, proses produksi, distribusi, konsumsi, dan pemasaran harus senantiasa dikaitkan dengan nilai-nilai Ilahiah dan harus selaras dengan tujuan yang telah ditetapkan olehNya.

Agar manusia dapat menjalankan tugas dengan baik sebagai khalifah Allah dimuka bumi, maka ia wajib tolong menolong dan saling membantu dalam melaksanakan kegiatan ekonomi yang bertujuan untuk beribadah kepada Allah SWT. Selain dari itu, manusia diperintahkan agar percaya pada hari kiamat, sebab segala tingkah laku ekonomi manusia akan dapat terkendali sebab ia sadar bahwa semua perbuatannya akan diminta pertanggungjawabannya kelak oleh Allah SWT.

2. Nilai Keadilan $\left(a l^{-}\right.$Ad $\left.\mathbf{l}\right)$

Salah satu prinsip yang sangat penting dalam melaksanakan kegiatan ekonomi Islam adalah keadilan. Berperilaku adil tidak hanya berdasarkan kepada Al-Qur'an dan Al-Hadis, tetapi didasarkan pula pada pertimbangan hukum alam, yang didasarkan pada keseimbangan dan keadilan. Keadilan dalam ekonomi dapat diterapkan secara menyeluruh, antara lain dalam penentuan harga, kualitas produk, perlakuan terhadap para pekerja, dan dampak dari kebijakan ekonomi yang dikeluarkan.

Keadilan dapat menghasilkan keseimbangan dalam perekonomian dengan meniadakan kesenjangan antara pemilik modal (kelebihan dana) dengan orang yang membutuhkan modal (dana). Islam juga tidak menganjurkan kesamaan ekonomi sebagaimana yang dianut oleh kaum sosialis, Islam mengakui adanya ketidaksamaan ekonomi antar orang per 
orang sebagaimana yang difirmankan oleh Allah SWT dalam Al-Qur'an Surat az-Zukhruf (43) ayat 32 yang artinya: "Apakah mereka yang membagi-bagi rahmat Tuhanmu? Kami telah menentukan antara mereka penghidupan mereka dalam kehidupan dunia, dan kami telah meninggikan sebagian mereka atas sebagian yang lain beberapa derajat, agar sebagian mereka dapat menggunakan sebagian yang lain. Dan rahmat Tuhanmu lebih hak dari apa yang kamu kumpulkan."

3. Nilai Kenabian (al-Nubuwah)

Nilai kenabian adalah merupakan salah satu nilai yang universal dalam ekonomi Islam, sebab fungsi Nabi Muhammad SAW adalah sebagai sentral pembawa syariat Islam di dunia ini. Sifat-sifat dasar yang sangat mempengaruhi perilaku Nabi Muhammad SAW dalam berbisnis yaitu sifat shiddiq (kebenaran), amanah (terpercaya), fathonah (cerdas), dan tabligh (komunikatif), merupakan suri tauladan yang dapat diikuti oleh umatnya, terutama dalam bidang bisnis yang digelutinya agar dapat berkembang dan maju sesuai dengan syariat Islam. Di samping itu, dalam diri Rasulullah terdapat sifat lain yang perlu diteladani yaitu keberanian mampu mengambil keputusan yang tepat, pandai dalam menganalisis dan situasi, dan cepat tanggap terhadap segala perubahan yang terjadi dalam bidang ekonomi.

4. Nilai Pemerintahan (al-Khalifah)

Peran negara diperlakukan dalam instrumentasi dan fungsionalisasi nilainilai ekonomi Islam dalam aspek legal, perencanaan dan pengawalannya, pengalokasian distribusi sumber-sumber dan dana, pemerataan dan pendapatan dan kekayaan serta pertumbuhan dan stabilitas ekonomi. Semua campur tangan ini harus menghasilkan individu dan masyarakat yang saleh, saling sayang menyayangi, dan bekerjasama dalam kebaikan serta taqwa kepada Allah SWT. Dalam kaitan ini, Muhammad mengatakan bahwa tugas negara adalah berupaya untuk menegakkan kewajiban dan keharusan mencegah terjadinya hal-hal yang diharamkan, khususnya dosa besar seperti riba, perampasan hak, pencurian, kezaliman kaum kuat terhadap kaum lemah. (Muhammad, 2004: 83).

Oleh karena pemerintah sebagai pemilik manfaat sumber-sumber ekonomi yang bersifat publik, termasuk produksi dan distribusi serta sebagai lembaga pengawas kehidupan ekonomi, maka pemerintah berhak campur tangan dalam kegiatan ekonomi yang dilaksanakan oleh individu dan masyarakat. Ikut campur pemerintah ini bukan berarti pemerintah berhak memonopoli segala sektor ekonomi negara. Semua campur tangan negara ini harus menghasilkan individu dan masyarakat yang saleh yang mendapat ridha dari Allah SWT. Dalam kaitan ini, Yusuf al-Qardhawi, menjelaskan bahwa tugas negara adalah mengubah pemikiran menjadi amal perbuatan, memindahkan moralitas kepada praktik-praktik konkret, mendirikan berbagai lembaga dan instansi yang dapat melaksanakan tugas penjagaan dan pengembangan semua hal tersebut. Tugas negara juga harus memonitoring pelaksana tentang sejauh manakah pelaksanaan dan ketidakdisiplinan terhadap kewajiban yang diminta dan menghukum orang yang melanggar atau melalaikan pelecehan dalam kehidupan bersama. (Yusuf al-Qardhawi, 2000: 13 dan 83).

5. Hasil atau Keuntungan (al-Ma'ad) 
Karakteristik ekonomi Islam mengakui ada dua tujuan yang harus dicapai oleh setiap orang selaku pelaksana ekonomi yaitu tujuan hidup dunia akhirat. Dalam ekonomi Islam, pelaksanaan segala bentuk aktivitas ekonomi harus mempunyai nilai ganda tersebut dan hal ini harus berimplikasi pada keseriusan berusaha karena adanya pertanggungjawaban dunia akhirat sekaligus. Seorang pelaku ekonomi Islam, baik individu maupun negara harus memiliki karakteristik time horizon agar tujuan ekonomi yang hendak dicapai dapat terlaksana dengan baik. Tujuan ini ialah kesejahteraan dunia (profit oriented) dan kesejahteraan diakhirat kelak (falah oriented).

\section{Kasus dan Penyelesaian di Pengadilan Agama}

Apabila seseorang atau badan hukum telah melakukan akad syariah dengan pihak lain, maka antara pihak tersebut telah terjalinnya perikatan. Oleh karena itu, menurut hukum perdata, kesepakatan yang telah disetujui para pihak tersebut akan mengikat sebagai undang-undang bagi mereka yang membuatnya. (Pasal 1338 ayat (1) KUH Perdata). Dengan demikian, terjadinya suatu sengketa ekonomi syariah disebabkan oleh dua belah pihak, baik perorangan maupun badan hukum yang melakukan akad atau perjanjian dengan prinsip syariah yang salah satu pihak melakukan wanprestasi dan/atau melakukan perbuatan melawan hukum, sehingga mengakibatkan pihak yang lainnya merasa dirugikan. Misalnya: A sebagai nasabah melakukan akad pinjam meminjam pada Bank Syariah, sebesar Rp.200.000.000,- (dua ratus juta rupiah) dengan angsuran perbulan sesuai dengan kesepakatan antara A sebagai nasabah dengan Bank Syariah tersebut. Bulan pertama dan kedua, angsuran tersebut lancar dibayar oleh A, namun pada bulan berikutnya A tidak membayar angsuran dengan berbagai macam alasan atau angsuran macet, sehingga mengakibatkan pihak Bank Syariah merasa dirugikan. Keadaan tersebut mengakibatkan terjadinya sengketa ekonomi syariah yang disebabkan adanya "wanprestasi".

Wanprestasi berasal dari bahasa Belanda yang artinya "prestasi buruk", sedangkan menurut kamus wanprestasi artinya kelalaian, kealpaan, cidera janji, dan tidak menepati janji dalam perjanjian. (Sudarsono, 2007: 578). Menurut Yahya Harahap, wanprestasi sebagai pelaksanaan kewajiban yang tidak tepat pada waktunya atau dilakukan tidak menurut selayaknya, sehingga menimbulkan keharusan bagi pihak debitur untuk memberikan atau membayar ganti rugi (schadevergoeding), atau dengan adanya wanprestasi oleh salah satu pihak, pihak yang lainnya dapat menuntut pembatalan perjanjian. Menurut J. Satrio, wanprestasi adalah suatu keadaan dimana debitur tidak memenuhi janjinya atau tidak memenuhi sebagaimana mestinya dan semua itu dapat dipersalahkan kepadanya. Dengan demikian, maka unsur prestasi itu adalah berbuat sesuatu, tidak berbuat sesuatu, dan menyerahkan sesuatu. Apabila unsur-unsur prestasi tersebut tidak dilaksanakan sebagaimana mestinya, maka akan terjadi wanprestasi.

Secara umum bentuk wanprestasi adalah sebagai berikut:

a. Tidak melaksanakan prestasi sama sekali.

b. Melaksanakan tetapi tidak tepat waktu atau terlambat dari yang diperjanjikan sebelumnya.

c. Melaksanakan tetapi tidak seperti yang diperjanjikan. 
d. Debitur melaksanakan yang menurut perjanjian tidak boleh dilakukan.

Tata cara yang dapat dilakukan apabila debitur wanprestasi yaitu sebagai berikut:

a. Sommatie/Somasi, yaitu peringatan tertulis yang diberikan oleh kreditur kepada debitur secara resmi melalui pengadilan. Somasi adalah teguran dari si berpiutang (kreditur) kepada si berutang (debitur) agar dapat memenuhi prestasi sesuai dengan isi perjanjian yang telah disepakati antara keduanya. Somasi ini diatur di dalam Pasal 1238 KUH Perdata dan Pasal 1243 KUH Perdata, dan;

b. Ingebreke Stelling, yaitu peringatan kreditur kepada debitur secara tersendiri dan tidak melalui pengadilan. (Wawan Muhwan Hariri, 2011: 111).

Terhadap debitur yang wanprestasi, maka somasi dilakukan minimal sebanyak dua kali oleh kreditur atau jurusita dilandasi dengan iktikad baik. Adapun jeda waktu antara somasi pertama dengan somasi kedua adalah satu minggu hari kerja. Namun, didalam praktiknya ditemukan di kalangan perbankan, memberikan somasi sebanyak 3 tiga kali. (Heri Shietra, 2016: 115). Apabila somasi tersebut tidak diindahkannya, maka kreditur berhak membawa persoalan tersebut ke pengadilan, selanjutnya pengadilan yang akan memutuskan, apakah debitur wanprestasi atau tidak.

Menurut Surat Edaran Mahkamah Agung (SEMA) Nomor 4 Tahun 2016, berkaitan dengan gugatan wanprestasi di bidang ekonomi syariah, maka hakim tidak boleh membatalkan akad syariah yang sudah dibuat oleh para pihak, yang apabila menurut penilaian hakim tidak sesuai dengan prinsip syariah, apabila dalam hal tersebut tidak ada gugatan pembatalan akad dari para pihak. Jika terjadi wanprestasi meskipun belum jatuh tempo pelunasan pembayaran, maka terhadap hak tanggungan atas akad tersebut dapat dieksekusi yang tentunya setelah diberi peringatan (somasi) sesuai dengan ketentuan yang berlaku.

Akibat hukum/sanksi hukum bagi debitur yang wanprestasi adalah sebagai berikut:

a. Membayar kerugian yang diderita oleh kreditur, yang berupa pembayaran ganti rugi.

b. Pembatalan perjanjian.

c. Peralihan resiko, di mana benda yang dijanjikan berupa objek perjanjian, sejak saat tidak dipenuhinya kewajiban menjadi tanggung jawab dari kreditur.

d. Membayar biaya perkara, kalau sampai diperkarakan di depan hakim melalui pengadilan.

Berdasarkan Pasal 1276 KUH Perdata yang dapat dilakukan oleh kreditur dalam menghadapi debitur yang wanprestasi adalah sebagai berikut:

a. Memenuhi atau melaksanakan perjanjian.

b. Memenuhi perjanjian disertai keharusan membayar ganti rugi.

c. Membayar ganti rugi.

d. Membatalkan perjanjian.

e. Membatalkan perjanjian disertai dengan ganti rugi.

Terhadap debitur yang dituntut membayar ganti rugi tidak sertamerta bersifat absolut, karena debitur dapat melakukan pembelaan yaitu sebagai berikut: 
a. Adanya keadaan memaksa (Overmacht/Force Majeure) yaitu suatu keadaan dimana debitur tidak dapat melakukan prestasinya kepada kreditur, yang disebabkan adanya kejadian yang diluar kekuasaannya, misalnya disebabkan barang yang diperjanjikan hilang atau musnah, atau karena terjadi bencana alam dan lain sebagainya.

b. Adanya kelalaian dari pihak kreditur itu sendiri (Exeptio Non Adimreti Contractus).

c. Kreditur telah melepaskan haknya untuk menuntut ganti rugi (Rechtsverweking).

Menurut Pasal 1365 BW menyatakan "bahwa tiap perbuatan melawan hukum yang menyebabkan oranglain menderita kerugian, mewajibkan siapa yang bersalah karena menyebabkan kerugian itu harus mengganti kerugian tersebut". Dengan demikian, adanya perbedaan antara perbuatan melawan hukum dengan wanprestasi. Dalam perbuatan melawan hukum tidak harus ada hubungan kontraktual terlebih dahulu, sepanjang perbuatan itu menyebabkan kerugian, maka pihak yang merasa dirugikan dapat mengajukan tuntutan/gugatan kepada pihak yang menimbulkan kerugian, sedangkan dalam wanprestasi, harus ada hubungan kontraktual terlebih dulu diantara para pihak, baru dapat dikatakan adanya wanprestasi. Perbuatan melawan hukum di bidang keperdataan dikenal dengan istilah onrechmatige daad.

Menurut Rosa Agustina, untuk dapat disebut sebagai perbuatan melawan hukum adanya empat syarat:

1. Melanggar hak subjektif orang lain.

Termasuk di dalamnya hak-hak pribadi, hak-hak kekayaan, hak atas kebebasan, hak atas kehormatan, dan nama baik.

2. Melanggar kewajiban hukumnya sendiri

Dalam substansi melanggar hukumnya sendiri, yaitu kewajiban yang diberikan oleh hukum terhadap seseorang, baik hukum tertulis maupun hukum tidak tertulis.

3. Melanggar etika pergaulan hidup.

Kategori melanggar pergaulan hidup apabila perbuatan melanggar etika atau susila tersebut menjadikan kerugian bagi orang lain.

4. Melanggar kewajiban sebagai anggota masyarakat.

Melanggar kewajiban sebagai anggota masyarakat, yaitu perbuatan yang bertentangan dengan prinsip kehati-hatian atas keharusan dalam pergaulan masyarakat yang baik. (Rosa Agustina, 2003: 117).

Penyelesaian sengketa ekonomi syariah itu dapat dilakukan secara nonlitigasi dan litigasi. Adapun penyelesaian sengketa ekonomi syariah secara nonlitigasi dapat diselesaikan melalui Alternatif Penyelesaian Sengketa (APS) atau dikenal dengan Alternative Dispute Resolution (ADR), penyelesaian melalui Arbitrase Syariah, dan melalui Lembaga Konsumen. Penyelesaian sengketa melalui Alternatif Penyelesaian Sengketa (APS) atau Alternative Dispute Resolution (ADR) diatur dalam Undang-Undang Nomor 30 Tahun 1999 tentang Arbitrase dan Alternatif Penyelesaian Sengketa. Yang termasuk kategori penyelesaian sengketa ekonomi syariah melalui Alternatif Penyelesaian Sengketa (APS) atau Alternative Dispute Resolution (ADR) yaitu sebgai berikut:

1. Musyawarah 
Arti kata musyawarah adalah mengambil madu dari sarang lebah, kemudian berkembang artinya sehingga mencakup segala sesuatu yang diambil dari orang termasuk pendapat (Iman Jauhari, 2009: 23). Sedangkan menurut Kamus Besar Bahasa Indonesia (KBBI), musyawarah artinya "pembahasan bersama dengan maksud mencapai keputusan atas penyelesaian masalah." (Mulyono, 1995: 677).

2. Mediasi

Menurut Kamus Besar Bahasa Indonesia (KBBI), mediasi adalah proses pengikutsertaan pihak ketiga dalam penyelesaian suatu sengketa, sedangkan mediator artinya perantara atau penghubung.

3. Konsultasi

Penyelesaian sengketa ekonomi syariah melalui konsultasi bersifat personal antara pihak-pihak yang disebut klien dengan lembaga pendamai yang disebut konsultan. Konsultan inilah yang membantu para pihak yang bersengketa untuk merumuskan dan membuat kesepakatan perdamaian dalam bentuk tertulis yang ditandatangani oleh kedua belah pihak dengan diketahui oleh konsultan tersebut.

4. Negosiasi

Negosiasi merupakan salah satu cara yang paling cepat, tepat, aman, dan konfidensial karena negosiasi adalah penyelesaian sengketa oleh para pihak tanpa melibatkan orang lain. Negosiasi merupakan komunikasi dua arah yang dirancang untuk mencapai kesepakatan pada saat kedua belah pihak memiliki berbagai kepentingan yang sama maupun berbeda, yang merupakan sarana bagi pihak-pihak yang bersengketa untuk mendiskusikan penyelesaiannya tanpa keterlibatan pihak ketiga (Suyud Margono, 2000: 23).

5. Konsiliasi

Konsiliasi adalah usaha mempertemukan keinginan pihak yang berselisih untuk mencapai persetujuan dan penyelesaian. Dalam menyelesaikan perselisihan, konsiliator memiliki hak dan kewenangan untuk menyampaikan pendapat secara terbuka dan tidak memihak kepada yang bersengketa. Selain itu, konsiliator tidak berhak untuk membuat keputusan dalam sengketa untuk nama dan atas nama para pihak sehingga keputusan akhir merupakan proses konsiliasi yang diambil sepenuhnya oleh para pihak dalam sengketa yang dituangkan dalam bentuk kesepakatan di antara mereka.

6. Penilaian Ahli

Penilaian ahli merupakan suatu upaya untuk mempertemukan pihak yang berselisih dengan cara menilai pokok sengketa, yang dilakukan oleh seseorang atau beberapa orang ahli di bidang terkait untuk mencapai persetujuan. Penilaian ahli berupa keterangan tertulis yang merupakan hasil telaahan ilmiah berdasarkan keahlian yang dimiliki untuk membuat terang pokok sengketa yang sedang dalam proses. Penilaian ahli ini dapat diperoleh dari seseorang atau tim ahli yang dipilih secara ad hoc.

Dalam Pasal 49 Undang-Undang Nomor 7 Tahun 1989 tentang Peradilan Agama dijelaskan tentang kewenangan dan kekuasaan mengadili yang menjadi beban tugas Peradilan Agama. Dalam pasal tersebut ditegaskan bahwa Pengadilan Agama bertugas dan berwenang memeriksa, memutuskan dan menyelesaikan perkara-perkara di tingkat pertama antara orang-orang yang beragama Islam di bidang perkawinan, kewarisan, wasiat 
dan hibah yang dilakukan berdasarkan hukum Islam, serta wakaf dan sedekah. Sedangkan Pengadilan Tinggi Agama berwenang dan bertugas mengadili perkara-perkara yang menjadi wewenang dan tugas Peradilan Agama dalam tingkat banding, juga menyelesaikan sengketa yurisdiksi antara Pengadilan Agama.

Undang-Undang Nomor 7 Tahun 1989 pada Pasal 49 sebagaimana tersebut di atas, diubah dengan Undang-Undang Nomor 3 Tahun 2006 dan tidak diubah pasal dan isinya pada perubahan kedua Undang-Undang Nomor 50 Tahun 2009 tentang Peradilan Agama, yang menyatakan bahwa "Pengadilan Agama bertugas dan berwenang memeriksa, memutus, dan menyelesaikan perkara di tingkat pertama antara orang-orang yang beragama Islam di bidang: a) Perkawinan, b) Kewarisan, c) Wasiat, d) Hibah, e) Wakaf, f) Zakat, g) Infak, h) Sedekah, dan i) Ekonomi Syariah.”

Yang dimaksud dengan ekonomi syariah adalah perbuatan atau kegiatan usaha yang dilaksanakan menurut prinsip syariah, antara lain:

a) Bank syariah;

b) Lembaga keuangan mikro syariah;

c) Asuransi syariah;

d) Reasuransi syariah:

e) Reksadana syariah;

f) Obligasi syariah dan surat berharga berjangka menengah;

g) Sekuritas syariah;

h) Pembiayaan syariah;

i) Pegadaian syariah;

j) Dana pensiun lembaga keuangan syariah; dan bisnis syariah.

Semakin lama semakin ada perkembangan hukum ekonomi syariah, sehingga banyak bermunculan sengketa ekonomi syariah sebagai kewenangan absolut dari Pengadilan Agama. Seiring dengan perkembangan tersebut, maka lahirlah Peraturan Mahkamah Agung (PERMA) Nomor 14 Tahun 2016 tentang Tata Cara Penyelesaian Sengketa Ekonomi Syariah.

Di dalam perkara sengketa ekonomi syariah yang dapat mengajukan perkara diantaranya yaitu: (Amran Suadi, 2017: 106-107).

1. Orang meliputi pribadi atau usaha perorangan.

Jika orang yang harus diperhatikan adalah identitas dirinya sedangkan jika usaha perseorangan yang harus diperhatikan dokumen-dokumen yang berkaitan.

2. Badan hukum meliputi perseroan terbatas, koperasi, yayasan, Badan Usaha Milik Negara atau Daerah, partai politik, organisasi massa, dan lainnya.

Jika yang mengajukan perkara dalam bentuk badan hukum, maka yang harus diperhatikan adalah kedudukan orang yang mewakili, serta anggaran dasar dari badan hukum tersebut. Pada Pasal 98 jo. Pasal 1 angka 5 Undang-Undang Nomor 40 Tahun 2007 tentang Perseroan Terbatas menyatakan bahwa direksi mewakili perseroan, baik di dalam maupun di luar pengadilan, sedangkan pada Pasal 99 menyatakan bahwa anggota direksi tidak berwenang mewakili perseroan apabila terjadi perkara di pengadilan. Apabila antara perseroan dan anggota direksi yang bersangkutan punya benturan kepentingan, maka yang mewakili adalah direksi yang tidak ada benturan kepentingan. Jika seluruh direksi punya benturan kepentingan, maka yang mewakili adalah dewan komisaris, 
kemudian jika dewan komisaris juga punya kepentingan maka siapa yang ditunjuk dari pihak lain oleh Rapat Umum Pemegang Saham (RUPS).

3. Bukan badan hukum seperti firma, Commanditaire Vennootschapp (CV). Pada kategori ini, ketentuan-ketentuan dan mekanisme usaha perseorangan atau pribadi. Oleh karena itu, yang perlu diperhatikan adalah dokumen-dokumennya serta susunan kepengurusannya.

Tujuan terpenting dari hukum adalah mewujudkan keadilan sosial yang terformulasi dalam tindakan menyerukan kebajikan dan mencegah kejahatan (al-amr bi al-ma'ruf wa an-nahy 'an al-munkar). Akan tetapi, siapa saja menghendaki suatu tujuan, konsekuensinya harus mau melaksanakan cara-cara untuk mencapai tujuan tersebut. Allah SWT menegakkan keadilan, memerangi orang-orang yang zalim, namun semua itu tidak akan terlaksana kecuali dengan kekuatan (kekuasaan) dan imarah (kepemimpinan). (Ibn Taimiyah, al-Siayash al-Syar'iyah, 1991: 149).

\section{Asas-Asas Hukum Acara Peradilan Agama}

Menurut Satjipto Rahardjo, bahwa asas hukum adalah jiwanya peraturan hukum, karena merupakan dasar lahirnya peraturan hukum, ialah ratio legis nya peraturan hukum. Asas hukum ini dapat ditemukan disimpulkan langsung ataupun tidak langsung dalam peraturan-peraturan hukum yang pada hakikatnya mengandung unsur asas-asas hukum yang bersangkutan. (Jimly Asshiddiqie, 2005: 66).

Adapun asas-asas Hukum Acara Peradilan Agama adalah sebagai berikut:

1. Personalitas Keislaman

Asas personalitas keislaman ini berbeda penerapannya pada perkara ekonomi syariah dengan perkara cerai gugat, cerai talak, hadhanah, harta bersama, dan lain sebagainya yang termasuk hukum keluarga, kewarisan, wasiat dan hibah, wakaf, zakat, infaq dan shadaqah. Pada perkara atau sengketa ekonomi syariah asas personalitas keislaman tidak dapat diterapkan, melainkan lebih kepada asas penundukan diri. Artinya, apabila pihak berperkara telah mengadakan akad syariah atau mengikuti kegiatan bisnis syariah, maka berarti yang bersangkutan telah menundukkan diri terhadap hukum Islam dalam bidang ekonomi syariah, dengan demikian meskipun yang bersangkutan beragama non muslim, maka penyelesaian sengketanya tetap diajukan di Pengadilan Agama. Sedangkan pada perkara selain perkara ekonomi syariah sebagaimana tersebut diatas, maka para pihaknya harus sama-sama beragama Islam.

2. Asas Bebas Merdeka

Dalam Penjelasan Pasal 1 Undang-Undang Nomor 4 Tahun 2004 menyebutkan bahwa: "Kekuasaan kehakiman yang merdeka mengandung pengertian bahwa kekuasaan kehakiman yang bebas campur tangan pihak kekuasaan negara lainnya dan kebebasan dari paksaan, direktiva, atau rekomendasi yang datang dari pihak ekstrayudisial, kecuali dalam hal yang diizinkan undang-undang."

3. Asas sebagai Pelaksana Kekuasaan Kehakiman

Dalam Pasal 10 Undang-Undang Nomor 4 Tahun 2004 dijelaskan bahwa:

(1) Kekuasaan kehakiman dilakukan oleh sebuah Mahkamah Agung dan Badan Peradilan yang berada di bawahnya, dan oleh sebuah Mahkamah 
Konstitusi; (2) Badan peradilan yang berada di bawah Mahkamah Agung meliputi badan peradilan dalam lingkungan peradilan umum, peradilan agama, peradilan militer, dan peradilan tata usaha negara.

4. Asas Ketuhanan

Peradilan Agama dalam menerapkan hukumnya selalu berpedoman pada sumber hukum Islam, sehingga pembuatan putusan ataupun penetapan harus dimulai dengan kalimah "Bismillahirrahmanirrahim", yang diikuti dengan irah-irah "Demi Keadilan Berdasarkan Ketuhanan Yang Maha Esa”.

5. Asas Fleksibilitas (Speedy Administration of Justice) atau Asas Sederhana, Cepat dan Biaya Ringan.

Maksudnya pemeriksaan perkara harus dilakukan dengan sederhana, cepat, dan biaya ringan. Asas ini diatur dalam Pasal 57 ayat (3) UndangUndang Nomor 7 Tahun 1989, yang pasal dan isinya tidak diubah sebagaimana perubahan pertama dan kedua yaitu Undang-Undang Nomor 3 Tahun 2006 dan Undang-Undang Nomor 50 Tahun 2009 tentang Peradilan Agama.

6. Asas Legalitas

Pengertian makna legalitas pada prinsipnya sama dengan pengertian "rule of law", artinya pengadilan yang berfungsi dan berwenang menegakkan hukum melalui badan peradilan harus berpijak dan berlandaskan hukum. Hakim yang berfungsi dan berwenang menggerakan jalannya roda peradilan melalui badan pengadilan, tidak boleh bertindak di luar hukum. Semua tindakan yang dilakukan dalam rangka menjalankan fungsi dan kewenangan peradilan mesti menurut hukum.

7. Asas Legitima Persona Standi in Judicio

Semua orang yang terkait langsung dalam perkara yang diajukan di muka persidangan harus masuk/dimasukan sebagai pihak-pihak dalam perkara apakah pihak-pihak itu sebagai Penggugat atau Tergugat.

8. Asas Ultra Pertium Partem

Hakim tidak boleh menjatuhkan putusan atas perkara yang tidak diminta atau hakim mengabulkan lebih dari yang dituntut.

9. Asas Audi et Alteram Partem

Hakim wajib menyamakan kedudukan para pihak yang berperkara di muka persidangan. Artinya, pengadilan dalam mengadili para pihak harus ada unsur-unsur kesamaan derajat, kesamaan hak di persidangan, dan para pihak mempunyai kedudukan yang sama di muka persidangan.

10. Asas Unus Testis Nullus Testis

Artinya satu saksi bukan saksi, maksudnya bahwa seorang saksi tanpa ada alat bukti lain dianggap belum mencapai batas minimal pembuktian. Agar pembuktian tersebut mencapai batas minimal, maka harus ada alat bukti lainnya.

11. Asas Actor Squitur Forum Rei

Gugatan diajukan di Pengadilan mana benda tidak bergerak itu berada atau terletak.

12. Asas Upaya Perdamaian (Ishlah)

Setiap persidangan hakim harus mendamaikan para pihak yang berperkara. Apabila Para pihak yang berperkara hadir kedua-duanya (Penggugat/Pemohon dan Tergugat/Termohon), maka wajib ditempuh 
upaya mediasi terlebih dahulu sebagaimana ketentuan Peraturan Mahkamah Agung Nomor 01 Tahun 2016, yang bersifat imperatif.

13. Asas Persidangan Terbuka untuk Umum

Asas ini bertujuan agar persidangan berjalan secara fair, menghindari adanya pemeriksaan yang sewenang-wenang atau menyimpang dan agar jalannya sidang pemeriksaan berlangsung dalam suasana "fair trail" (pemeriksaan sidang yang fair), tidak memihak dan tidak berat sebelah, sehingga berdampak "edukasi" dan "prepensi". Pemeriksaan sidang yang terbuka untuk umum dapat menjadi bahan informasi bagi anggota masyarakat tentang suatu kasus peristiwa. Dari bahan informasi yang terpantul dari kasus peristiwa yang diperkarakan akan memberi pelajaran bagi masyarakat bagaimana bersikap dan bertingkah laku yang tidak bertentangan dengan hukum. Penerapan asas persidangan terbuka untuk umum dikecualikan dalam pemeriksaan perkara perceraian, dengan demikian pemeriksaan dilakukan dalam sidang tertutup untuk umum, dengan tujuan untuk menjamin kerahasiaan aib rumah tangga dan pribadi suami istri, sehingga bersifat imperatif. Apabila pemeriksaan perkara perceraian tidak dilakukan tertutup untuk umum, maka pemeriksaan perkara tersebut batal demi hukum, yang mengakibatkan putusannya juga batal demi hukum.

14. Asas Equality

Pengertian asas "equality" berarti persamaan hak. Jika asas ini dikaitkan dengan fungsi peradilan, berarti setiap orang yang datang berhadapan di sidang pengadilan adalah sama hak dan kedudukannya. Dengan kata lain sama hak dan kedudukan di hadapan hukum. Ada tiga patokan yang paling fundamentum dalam menerapkan persamaan hak dan kedudukan dalam proses peradilan yaitu: 1) persamaan hak dan derajat dalam proses pemeriksaan persidangan pengadilan (equal before the law), 2) hak perlindungan yang sama oleh hukum (equal protection on the law), dan 3) mendapat hak perlakuan yang sama di bawah hukum atau (equal justice under the law).

15. Asas Ratio Decidendi

Semua putusan pengadilan, selain harus memuat alasan dan dasar putusan tersebut, memuat pula pasal tertentu dan peraturan perundangundangan yang bersangkutan atau dasar hukum tidak tertulis yang dijadikan dasar untuk mengadili dan setiap putusan harus memuat pertimbangan hukum yang didasarkan pada alasan-alasan penilaian dan dan dasar hukum yang tepat dan benar.

Dengan adanya penambahan kewenangan absolut Pengadilan Agama dalam mengadili sengketa ekonomi syariah, maka diperlukan seperangkat aturan hukum. Diantara perangkat hukum dalam penyelesaian sengketa ekonomi syariah secara litigasi di Pengadilan Agama, maka dikenal ada 2 tata cara penyelesaian sengketa ekonomi syariah tersebut yaitu pertama dengan acara sederhana dan kedua dengan acara biasa.

1. Penyelesaian Sengketa Ekonomi Syariah dengan Acara Sederhana

Di dalam PERMA Nomor 14 Tahun 2016 tentang Tata Cara Penyelesaian Perkara Ekonomi Syariah, pada Bab III mengatur tentang Tata Cara Pemeriksaan Perkara Dengan Acara Sederhana. Gugatannya dapat diajukan secara lisan atau tertulis dalam bentuk cetak atau pendaftaran perkara secara elektronik. Pemeriksaan perkara dengan acara sederhana 
adalah pemeriksaan terhadap perkara ekonomi syariah yang nilainya paling banyak Rp.200.000.000,- (dua ratus juta rupiah), yang diselesaikan dengan tata cara dan pembuktiannya sederhana, serta mengacu pada PERMA Nomor 2 Tahun 2015 tentang Tata Cara Penyelesaian Gugatan Sederhana kecuali hal-hal yang diatur secara khusus dalam Peraturan Mahkamah Agung ini. Perkara ekonomi syariah harus sudah diputus berdasarkan tenggang waktu sebagaimana dimaksud pada Surat Edaran Mahkamah Agung (SEMA) Nomor 2 Tahun 2014 tentang Penyelesaian Perkara di Pengadilan Tingkat Pertama dan Tingkat Banding pada 4 (empat) Lingkungan Peradilan.

Keberatan adalah upaya hukum terhadap putusan hakim dalam gugatan sederhana. Keberatan diajukan kepada Ketua Pengadilan dengan menandatangani akta pernyataan keberatan dihadapan panitera diserati alasan-alasannya. Permohonan keberatan diajukan paling lambat 7 (tujuh) hari setelah putusan diucapkan atau setelah pemberitahuan putusan. Permohonan keberatan diajukan kepada Ketua Pengadilan dengan mengisi blanko permohonan keberatan yang disediakan di kepaniteraan. Apabila permohonan keberatan diajukan melampui batas waktu pengajuan, maka dinyatakan tidak dapat diterima dengan penetapan ketua pengadilan berdasarkan surat keterangan panitera. Putusan terhadap permohonan keberatan diucapkan paling lambat 7 (tujuh) hari setelah tanggal penetapan Majelis Hakim. Pemberitahuan putuan keberatan disampaikan kepada para pihak paling lambat 3 (tiga) hari sejak diucapkan. Putusan keberatan berkekuatan hukum tetap terhitung sejak disampaikannya pemberitahuan. Putusan keberatan merupakan putusan akhir yang tidak tersedia upaya hukum banding, kasasi atau peninjauan kembali.

Dalam penyelesaian sengketa atau perkara ekonomi syariah hakimnya adalah hakim tunggal. Tidak termasuk dalam gugatan sederhana adalah a) perkara yang penyelesaian sengketanya dilakukan melalui pengadilan khusus sebagaimana diatur didalam peraturan perundang-undangan; atau b) sengketa hak atas tanah.

Para pihak dalam gugatan sederhana terdiri dari Penggugat dan Tergugat yang masing-masing tidak boleh lebih dari satu, kecuali memiliki kepentingan hukum yang sama. Terhadap Tergugat yang tidak diketahui tempat tinggalnya, tidak dapat diajukan gugatan sederhana. Penggugat dan Tergugat dalam gugatan sederhana berdomisili di daerah hukum Pengadilan yang sama. Penggugat dan Tergugat wajib menghadiri secara langsung setiap persidangan dengan atau tanpa didampingi oleh kuasa hukum.

Tahapan penyelesaian gugatan sederhana meliputi sebagai berikut:

a. Pendaftaran;

b. Pemeriksaan kelengkapan gugatan sederhana;

c. Penetapan hakim dan penunjukkan panitera pengganti;

d. Pemeriksaan pendahuluan;

e. Penetapan hari sidang dan pemanggilan para pihak;

f. Pemeriksaan sidang dan perdamaian;

g. Pembuktian;

h. Putusan. 
Penyelesaian gugatan sederhana paling lama 25 (dua puluh lima) hari sejak hari sidang pertama. Dalam proses pemeriksaan gugatan sederhana, tidak dapat diajukan tuntutan provisi, eksepsi, rekonvensi, intervensi, replik, duplik, atau kesimpulan. Terhadap gugatan yang diakui dan/atau tidak dibantah, tidak perlu dilakukan pembuktian. Terhadap gugatan yang dibantah, hakim melakukan pemeriksaan pembuktian berdasarkan hukum acara yang berlaku.

Terhadap putusan yang tidak diajukan keberatan, apabila sudah berkekuatan hukum tetap dilaksanakan secara sukarela, apabila tidak dilaksanakan secara sukarela maka putusan dilaksanakan berdasarkan ketentuan hukum acara perdata yang berlaku.

\section{Penyelesaian Sengketa Ekonomi Syariah dengan Acara Biasa}

Dalam PERMA Nomor 14 Tahun 2016 tentang Tata Cara Penyelesaian Sengketa Ekonomi Syariah mengatur dua hal yang masingmasing jelas dasar hukumnya. Untuk gugatan sederhana berpedoman pada PERMA Nomor 2 Tahun 2015, sedangkan untuk gugatan biasa berpedoman pada hukum acara perdata yang berlaku kecuali yang telah diatur secara khusus dalam PERMA ini, dan aturan gugatan sederhana tidak bisa diberlakukan untuk menyelesaikan sengketa ekonomi syariah pada gugatan dengan acara biasa.

Pengadilan Agama dalam memeriksa, mengadili dan memutus dengan acara biasa dengan sekurang-kurangnya 3 (tiga) orang hakim kecuali undang-undang menentukan lain. Diantara hakim tersebut pada ayat (1) seorang bertindak sebagai ketua, dan yang lainnya sebagai hakim anggota. Majelis hakim tersebut harus memenuhi ketentuan yang diatur dalam PERMA Nomor 5 Tahun 2016 tentang Sertifikasi Hakim Ekonomi Syariah. Sebelum pemeriksaan perkara dimulai, hakim wajib dengan sungguh-sungguh mengupayakan perdamaian. Upaya damai tersebut mengacu pada ketentuan PERMA Nomor 1 Tahun 2016 tentang Prosedur Mediasi di Pengadilan.

Dalam hal pelaksanaan putusan perkara ekonomi syariah, hak tanggungan dan fidusia berdasarkan akad syariah dilakukan oleh Pengadilan dalam lingkungan Peradilan Agama. Pelaksanaan putusan arbitrase syariah dan pembatalannya, dilakukan oleh pengadilan dalam lingkungan Peradilan Agama dengan mengacu kepada Undang-Undang Nomor 30 Tahun 1999 tentang Arbitrase dan Alternatif Penyelesaian Sengketa.

Mekanisme pemeriksaan perkara ekonomi syariah dapat dilakukan dengan bantuan teknologi informasi, seperti pendaftaran perkara secara online, pemanggilan lanjutan atas kesepakatan para pihak, pemeriksaan ahli, semuanya dapat dilakukan dengan bantuan teknologi informasi. Oleh karenanya, dalam Pasal 5 ayat (1), (2) dan (3) Undang-Undang Nomor 11 Tahun 2008 tentang Informasi dan Transaksi Elektronik menentukan bahwa:

a. Informasi elektronik dan/atau dokumen elektronik dan/atau hasil cetaknya merupakan alat bukti hukum yang sah;

b. Informasi elektronik dan/atau dokumen elektronik dan/atau hasil cetaknya sebagaimana dimaksud pada ayat (1) merupakan 
perluasan dari alat bukti yang sah sesuai dengan hukum acara yang berlaku di Indonesia; dan

c. Informasi elektronik dan/atau dokumen elektronik dan/atau dokumen elektronik dinyatakan sah apabila menggunakan sistem elektronik dengan ketentuan yang diatur dalam undang-undang ini. Ketentuan ini merupakan satu langkah maju dalam memberikan pengakuan terhadap bukti-bukti berdasarkan hal-hal yang diberikan oleh informasi elektronika. (Susanti Adi Nugroho, 2015: 500).

Batas waktu penyelesaian sengketa ekonomi syariah dengan acara biasa yaitu di Pengadilan tingkat pertama adalah selama 5 bulan, sedangkan di Pengadilan Tingkat banding selama 3 bulan, dan di tingkat kasasi dan peninjauan kembali juga selama 3 bulan.

\section{Eksekusi atau Pelaksanaan Putusan dalam Sengketa Ekonomi Syariah}

Menurut M. Yahya Harahap yang dimaksud eksekusi yaitu merupakan tindakan hukum yang dilakukan oleh pengadilan kepada pihak yang kalah dalam suatu perkara merupakan aturan tata cara lanjutan proses dari pemeriksaan yang berkesinambungan dari keseluruhan proses hukum acara perdata (Harahap, 1991: 1). Menurut Sudikno Mertokusumo, eksekusi pada hakikatnya tidak lain adalah realisasi kewajiban pihak yang bersangkutan untuk memenuhi putusan yang tercantum dalam putusan tersebut. (Musthofa, 2007: 109). Sedangkan menurut R. Subekti yang dimaksud eksekusi adalah pelaksanaan suatu putusan yang sudah tidak dapat diubah lagi itu, ditatati secara sukarela oleh pihak yang bersengketa. Jadi, di dalam makna perkataan eksekusi sudah mengandung arti pihak yang kalah mau tidak mau harus menaati putusan itu secara sukarela sehingga putusan itu harus dipaksakan kepadanya dengan bantuan kekuatan umum. Yang dimaksud dengan kekuatan umum adalah polisi bahkan kalau perlu militer (angkatan bersenjata) (R. Subekti, 1989: 130).

Dengan demikian, apabila pihak yang kalah dalam sengketa ekonomi syariah tidak mau melaksanakan isi putusan secara sukarela, maka pihak yang menang dapat meminta pelaksanaan putusan tersebut dengan jalan eksekusi ke Pengadilan. Adapun bentuk-bentuk eksekusi dalam sengketa ekonomi syariah yaitu: a) eksekusi hak tanggungan, b) eksekusi putusan arbitrase syariah, dan c) eksekusi jaminan fidusia.

\section{Kesimpulan}

Dari uraian-uraian tersebut di atas maka dapat disimpulkan hal-hal sebagai berikut: Bahwa penyelesaian sengketa ekonomi syariah dapat diselesaikan secara litigasi melalui Pengadilan Agama dan nonlitigasi melalui Alternatif Penyelesaian Sengketa (APS) atau dikenal dengan Alternative Dispute Resolution (ADR), penyelesaian melalui Arbitrase Syariah, dan melalui Lembaga Konsumen. Bahwa dalam penyelesaian sengketa ekonomi syariah secara litigasi di Pengadilan Agama, yang merupakan kewenangan absolut Pengadilan Agama, dikenal ada 2 tata cara penyelesaian sengketa ekonomi syariah tersebut yaitu pertama dengan acara sederhana dan kedua dengan acara biasa. Di dalam hukum acara peradilan agama dikenal adanya asas personalitas keislaman. Asas ini berbeda penerapannya pada perkara ekonomi syariah dengan perkara cerai gugat, 
cerai talak, hadhanah, harta bersama, dan lain sebagainya yang termasuk hukum keluarga, kewarisan, wasiat dan hibah, wakaf, zakat, infaq dan shadaqah.

Pada perkara atau sengketa ekonomi syariah asas personalitas keislaman tidak dapat diterapkan, melainkan lebih kepada asas penundukan diri. Artinya, apabila pihak berperkara telah mengadakan akad syariah atau mengikuti kegiatan bisnis syariah, maka berarti yang bersangkutan telah menundukkan diri terhadap hukum Islam dalam bidang ekonomi syariah, dengan demikian meskipun yang bersangkutan beragama non muslim, maka penyelesaian sengketanya tetap diajukan di Pengadilan Agama. Sedangkan pada perkara selain perkara ekonomi syariah sebagaimana tersebut diatas, maka para pihaknya harus sama-sama beragama Islam.

\section{Daftar Pustaka}

Agustianto, 2002, Percikan Pemikiran Ekonomi Islam, Forum Kajian dan Kajian Perbankan Islam (FKEBI) bekerjasama dengan Penerbit Citapustaka Media, Bandung.

Asshiddiqie, Jimly. Aspek-Aspek Perkembangan Kekuasaan Kehakiman di Indonesia, 2005, UII Press, Yogyakarta.

Direktorat Jenderal Badan Peradilan Agama Mahkamah RI, 2013, Pedoman Pelaksanaan Tugas dan Administrasi Peradilan, Buku II.

------, 2017, Himpunan Peraturan Penyelesaian Perkara Ekonomi Syariah.

Harahap, M. Yahya. 1990, Kedudukan, Kewenangan dan Acara Peradilan Agama (Undang-Undang Nomor 7 Tahun 1989), Pustaka Kartini, Jakarta.

------, Ruang Lingkup Permasalahan Eksekusi Bidang Perdata, 1991, Gramedia, Jakarta.

Hariri, Wawan Muhwan. 2011, Hukum Perikatan, Pustaka Setia, Bandung.

Ibn Taimiyah, 1991, al-Siyasah al_syar'iyah fi Islah al-Ra'i wa al-Ra'iyah, Dar al-Afaq al Jadidah, Maroko.

Jauhari, Iman. 2009, Penyelesaian Sengketa di Luar Pengadilan Menurut Hukum Islam, Pustaka Bangsa Press, Medan.

Manan, Abdul. 2012, Hukum Ekonomi Syariah dalam Perspektif Kewenangan Peradilan Agama, Kencana Prenada Media Group, Jakarta.

-----, 2006, Penerapan Hukum Acara Perdata di Lingkungan Peradilan Agama, Kencana Prenada Media Group, Jakarta.

Margono, Suyud. 2000, Alternative Dispute Resolution dan Arbitrase: Proses Pelembagaan dan Aspek Hukum, Ghalia Indonesia, Jakarta.

Nugroho, Susanti Adi. 2015, Penyelesaian Sengketa Arbitrase dan Penerapan Hukumnya, Prenada, Jakarta.

Peraturan Mahkamah Agung Nomor 2 Tahun 2015 tentang Tata Cara Penyelesaian Gugatan Sederhana.

Peraturan Mahkamah Agung Nomor 1 Tahun 2016 tentang Prosedur Mediasi di Pengadilan.

Peraturan Mahkamah Agung Nomor 5 Tahun 2016 tentang Sertifikasi Hakim Ekonomi Syariah.

Peraturan Mahkamah Agung Nomor 14 Tahun 2016 tentang Tata Cara Penyelesaian Sengketa Ekonomi Syariah. 
R. Subekti, 1989, Hukum Acara Perdata, Bina Cipta, Bandung.

Agustina, Rosa. 2003, Perbuatan Melawan Hukum, Pascasarjana Fakultas Hukum UI, Jakarta.

Suadi, Amran. 2017, Penyelesaian Sengketa Ekonomi Syariah Teori \& Praktik, Kencana Prenada Media Group, Jakarta.

Sudarsono, 2007, Kamus Hukum, Rineka Cipta, Jakarta.

Undang-Undang Nomor 7 Tahun 1989 tentang Peradilan Agama.

Undang-Undang Nomor 3 Tahun 2006 tentang Perubahan Pertama UndangUndang Nomor 7 Tahun 1989 tentang Peradilan Agama.

Undang-Undang Nomor 50 Tahun 2009 tentang Perubahan Kedua UndangUndang Nomor 7 Tahun 1989 tentang Peradilan Agama.

Undang-Undang Nomor 30 Tahun 1999 tentang Arbitrase dan Alternatif Penyelesaian Sengketa. 